\title{
The Effect of Artificial Lights on Nocturnal Macrolepidoptera (Lepidoptera: Macroheterocera) Communities
}

\author{
Edit NAGY PINTÉRNÉ ${ }^{\mathrm{a}^{*}}-$ Zoltán PÖDÖR ${ }^{\mathrm{b}}$ \\ ${ }^{a}$ Institute of Silviculture and Forest Protection, University of Sopron, Sopron, Hungary \\ ${ }^{\mathrm{b}}$ Institute of Informatics and Economics, University of Sopron, Sopron, Hungary
}

\begin{abstract}
We examined the light sources and illuminated environments in Sopron's public areas and studied the impact they had on the composition of macrolepidopteran moth communities. We employed light traps with three different light sources in three differently illuminated environments (seminatural, transitional, urban) on 60 occasions during the summer period of 2012-2013 and 20 times in the seminatural area in the spring and autumn of 2014. In the first two years, we evaluated the number of individuals; in year three, we evaluated the number of species. In the first two years, the high-pressure sodium light in the seminatural site trapped the largest number of nocturnal lepidopteran specimens $(2,569)$, while the mixed HMLI light trapped the most individuals in the transitional $(1,098)$ and urban (822) areas. Based on the average number of individuals the first two years, we compared the locations and light sources. In terms of average number of specimens collected, significant differences emerged between two light sources and two locations. When we completed the species diversity index, we determined the compact fluorescent tube in spring and the high-pressure sodium light in the autumn showed the greatest values.
\end{abstract}

light pollution / Lepidoptera / light trapping / Sopron / illumination

Kivonat - A mesterséges fényforrások hatása az éjszakai nagylepke közösségek (Lepidoptera Macroheterocera) összetételére. Sopron város közterületein előforduló fényforrások és az ebből eredő eltérő megvilágítottságú környezet hatását vizsgáltuk az éjszakai nagylepke közösségek összetételére. Három különböző típusú fényforrással ellátott fénycsapdát használtunk három eltérö megvilágítottságú környezetben (természetközeli, átmeneti, városi). 2012-2013 év nyarán 60, 2014 tavaszán és öszén a természetközeli helyszínen 20 alkalommal gyüjtöttünk mintákat. Az első két évben egyedszám, a harmadik évben fajszám szerint végeztük a kiértékelést. Az éjszakai nagylepkék egyedszáma az első két évben a természetközeli területen volt a legmagasabb; a nagynyomású nátrium lámpánál $(2,569)$, az átmeneti $(1,098)$ és a városi területen (822) a HMLI kevert lámpa esetén. A fényforrások összehasonlításánál két helyszínen, a területek összehasonlításánál két fényforrás típusnál volt szignifikáns eltérés az egyedszámok átlaga között. A diverzitás vizsgálatnál a diverzitási mutatók tavasszal a kompakt fénycsőnél, ősszel a nátrium lámpánál mutattak nagyobb diverzitási értéket.

fényszennyezés / Lepidoptera / fénycsapázás / Sopron / megvilágítottság

\footnotetext{
*Corresponding author: pinterne.nagy.edit@uni-sopron.hu; H-9400 SOPRON, Bajcsy-Zs. u. 4, Hungary
} 


\section{INTRODUCTION}

Artificial light sources (streetlights, houses, advertising lights, automobile lights) affect the natural brightness of the night sky and thus exert negative effects on the environment of nocturnal organisms. Illumination emitted from artificial light sources causes ecological light pollution (Horváth et al. 2009), which is spreading at an increasing rate over built environments and is expanding into other habitats. Aristotle was among the first in antiquity to make note of the attraction light sources had on insects at night (Kovács 1962). Nocturnal moths are especially prone to the lure of artificial light sources. Moths are the most significant nocturnal pollinators of flowers and plants (MacGregor et al. 2015), and face the same dangers as butterflies: habitat fragmentation, climate change, pesticides (Fox at al. 2014), and in recent decades, increasing light pollution (Hölker et al. 2010). Artificial lights inhibit the release of pheromones in female moths and effect ovipositioning (Nemec 1969, Sower et al. 1970). If a moth oviposits an unusually high density of eggs in a small space in an unsuitable location near light, the result is an ecological trap (Pfrimmer et al. 1955, Brown 1984) that increases competition for limited food sources among caterpillars (MacGregor et al. 2015). Moths clustering around artificial light sources like lamps also expose themselves to greater risk of predation by spiders, bats, reptiles, and amphibians (Howe 1959, Rydell 1992, Heiling 1999, Henderson - Powell 2001). Thus, increasing light pollution has resulted in significantly reduced moth populations in some European countries (MacGregor et al. 2015).

There are number of studies that deal with the decrease of individuals in pollinator populations around the world, but these focus mainly on diurnal insects (Williams 1982, Potts et al. 2010, Carvalheiro et al. 2013).

There are a number of studies focusing on the level of attraction to various lights within the orders of insect species. Frost (1954) experimented with black (100 W) and white (10 W) lights both together and separately. He experienced black light attracts most insects of the Diptera order, while white light attracted the greatest number of individuals from the Miridae and Chrysopidae orders. In India, monitoring investigations with mercury vapour lamps, black lamps and UV lamps have been carried out. After assessing these light traps, it was found that the mercury vapour lamp attracted the greatest number of individual specimens from the Lepidoptera, Hymenoptera, Hemiptera, Odonata and Diptera orders while the black lights attracted the greatest number of insects from the Coleoptera, Orthoptera, Isoptera and Dictyoptera orders. The UV lamp collected the greatest number of insects from the Orthoptera, Diptera and Dermaptera orders (Ramamurthy et al. 2010). Eisenbeis - Hassel (2000) light trapped in three differing areas including a residential village (with some garden ponds), a farmhouse site and a road site near a village. The lamps were high-pressure mercury vapour $(80 \mathrm{~W})$ or high-pressure sodium vapour $(70 \mathrm{~W}$ or $50 \mathrm{~W})$ and high-pressure sodium-xenon vapour $(80 \mathrm{~W})$. For special purposes, some of the high-pressure mercury vapour lamps were fitted with ultraviolet absorbing filters over the glass cover of the luminaires. The highpressure mercury vapour light attracted the greatest number of insects and the high-pressure mercury vapour light with filter attracted the fewest. Walker - Galbreath (1979) experimented with four types of lights. The mixed mercury vapour lamp $(160 \mathrm{~W})$ attracted twice as many insects the black light $(8 \mathrm{~W})$. The black light $(8 \mathrm{~W})$ collected double the insects than the white or kerosene lamps $(8 \mathrm{~W})$ did.

Our study is important because it examines the relationship between artificial lights and nocturnal macrolepidopteran moths and draws attention to the dangers artificial lights pose to these populations. 
The aim of this study is to investigate different types of illumination in the environment especially those originating from artificial light sources - and the effect these have on the number of lepidopteran individuals collected by light-traps in the summer. Furthermore, the study compares the diversity of the lepidopteran community collected by different artificial lights in the spring and in the autumn. In addition to this, we compare the diversity of lepidopteran communities that we attracted to the various light in both spring and autumn. We assumed that of the three location we used, the greatest number of lepidopteran individuals would occur in the seminatural area. Moreover, we also assumed that the HMLI lamp would produce the highest diversity value of collected lepidopteran communities in the spring and in the autumn as well.

\section{MATERIALS AND METHODS}

\subsection{Study area}

We selected three areas of different illumination intensity in Sopron and its surrounding for light-trapping. We termed the sites as follows: seminatural, transitional and urban. The seminatural study area is devoid of artificial lights, has virtually no light pollution, and is located in the Sopron highlands $\left(47^{\circ} 40^{\prime} \mathrm{N}, 16^{\circ} 27^{\prime} \mathrm{E}\right)$. The characteristic tree species of the area include beech, hornbeam, sessile oak, sporadically, common alder, birch, crack willow and aspen (Dövényi 2010). The transitional area had slight to moderate light pollution in the area caused by street lamps and illumination of local residences. The transitional site of our study is located in Bánfalva, which is a suburb of Sopron. The tree species present in this area are: cherry, linden, silver fir and white birch $\left(47^{\circ} 68^{\prime} \mathrm{N}, 16^{\circ} 55^{\prime} \mathrm{E}\right)$. The urban area is located at the meteorological station, which is in the centre of Sopron; there is significant light pollution from artificial light in this area. The meteorological station was built in 1972 and the park around it was constructed on a limestone foundation with artificial fill. The park contains several shrub and tree species including cherry laurel, hornbeam, common spindle, oriental thuja, and Russian olive ( $\left.47^{\circ} 40^{\prime} \mathrm{N}, 16^{\circ} 30^{\prime} \mathrm{E}\right)$.

\subsection{Sampling design}

Nocturnal moths specimens were collected in the summers (June, July and August) of 2012 and 2013 as well as in the spring (March, April) and autumn (October, November) of 2014 (Table 1). Nocturnal moth specimens were collected on 60 occasions in the years 2012 and 2013 and on 20 occasions in 2014 (Table 1). The sampling times were in three-day cycles adjusted to the new moon, the prime of the moon, the wane of the moon, and full moon. For our research, we used Jermy-type light-traps with three different light sources. The individuals collected by light-trapping were killed with ethyl acetate. In 2012 and in 2013, we employed one light trap in each area; we exchanged the lights in each area in three-day cycles (Photo 1, 2, 3 in Appendix). We utilized all three kinds of light traps simultaneously only in the seminatural area where we separated the light traps from each other with plank dividers (Photo 4 in Appendix). Light trapping went on for the entire duration of the night, from sunset to sunrise. Based on prior information and knowledge, we used the following three kinds of light sources: a high-pressure sodium lamp $(150 \mathrm{~W}, 1950 \mathrm{~K}, 17500 \mathrm{~lm})$, a HMLI mixed lamp $(160 \mathrm{~W}, 4200 \mathrm{~K}, 3100 \mathrm{~lm})$, and a compact fluorescent tube $(36 \mathrm{~W}, 4000 \mathrm{~K}, 2900 \mathrm{~lm})$. We selected these light sources because they were the most commonly occurring ones in residential settlements. 
Table 1. Light- trapping dates in the first two years

\begin{tabular}{|c|c|c|c|}
\hline Years & June & July & August \\
\hline 2012 & $\begin{array}{l}10 ; 11 ; 12 ; 18 ; \\
19 ; 20 ; 26 ; 28\end{array}$ & $\begin{array}{l}2 ; 3 ; 4 ; 10 ; 12 ; \\
17 ; 18 ; 19 ; 27 ; 28\end{array}$ & $\begin{array}{l}7 ; 8 ; 9 ; 16 ; 17 ; 18 ; \\
23 ; 24 ; 25 ; 30 ; 31\end{array}$ \\
\hline 2013 & $\begin{array}{l}7 ; 8 ; 9 ; 15 ; 16 ; 17 ; \\
22 ; 23 ; 24 ; 29 ; 30\end{array}$ & $\begin{array}{l}1 ; 7 ; 8 ; 9 ; 15 ; \\
16 ; 17 ; 28 ; 29 ; 30\end{array}$ & $\begin{array}{l}5 ; 6 ; 7 ; 13 ; 14 ; \\
15 ; 21 ; 22 ; 23\end{array}$ \\
\hline Years & March & October & November \\
\hline 2014 & $29 ; 30 ; 31$ & $14 ; 15 ; 16 ; 22 ; 23 ; 24 ; 30 ; 31$ & $1 ; 5 ; 6 ; 7 ; 13 ; 14 ; 15$ \\
\hline
\end{tabular}

We counted the collected lepidopteran individuals in 2012 and in 2013, and on the species level in 2014. The following literature was used for identification: Reichholf-Riehm (1996), McGavin (2000a, b), Sterry-Mackay (2004), MacGavin (2005), Varga (2010).

\subsection{Data analysis}

We analysed the results in two ways. The first analysis was based on the number of collected Lepidoptera individuals in the three areas in the summer 2012 and 2013. We investigated the correlation between the different illumination areas and the number of lepidopteran individuals collected. For the analysis of the average number of individuals, we made a comparison of the locations and light sources used based on the average number of collected lepidopteran specimens. Using the nonparametric Kruskal-Wallis $\mathrm{H}$ test, we examined data lines to determine if they could stem from same distribution (the test in accordance ANOVA nonparametric); this examination had a $95 \%$ level of trustworthiness. We used a Statistica 12 program for the assessment and with the help of the Lilliefors and Shapiro test we employed a normalization investigation. The results of this determined that the collected data was usually within the range of normal distribution (Kemény et al. 2011); the evidence for this were the „p" values, which were smaller than $0.05(\alpha=0.05)$ in many cases, but did not hold true for every pattern. In the second analysis, community ecological comparisons were completed on Lepidoptera assemblages collected by the various light traps using the Past program (Paleontological Statistics Software 2.17) (Hammer et al. 2012). We measured and compared the light attraction of lepidopteran communities to various light sources with the Jaccard similarity index (Raup-Crick 1979). To determine lepidopteran diversity, the Shannon index, Simpson index were calculated, and a Pielou-type equitability test (Krebs 1985). To compare diversity values, we used the Rényi diversity profiles (Tóthmérész 1997). To determine the species dominance of the lepidopteran communities, we utilized the Berger-Parker dominant index (Southwood 1984).

\section{RESULTS}

Summarised, 10,902 individuals of Lepidoptera were collected in 2012 and 2013. Of the three areas, the greatest number of individuals collected was in the seminatural area $(6,568)$ using the HMLI mixed lamp $(5,145)$ (Table 2). When we compare the catch results based on light source, the high-pressure sodium lamp in the seminatural area yielded the largest number of individuals $(2,569)$ while in the transitional $(1,989)$ and urban area $(822)$ the HMLI mixed lamp yielded the most individuals specimens. 
Table 2. Number of collected Lepidoptera individuals

\begin{tabular}{lccc}
\hline 2012 & & & \\
\hline Area/Lamp & seminatural & transitional & urban \\
\hline High-pressure sodium lamp & 938 & 194 & 200 \\
HMLI mixed lamp & 780 & 532 & 429 \\
Compact fluorescent tube & 750 & 183 & 224 \\
\hline 2013 & & & \\
\hline High-pressure sodium lamp & 1631 & 188 & 278 \\
HMLI mixed lamp & 1554 & 566 & 393 \\
Compact fluorescent tube & 915 & 124 & 78 \\
\hline
\end{tabular}

There was no significant difference among light sources in the seminatural area $(p>0.99)$. In the transitional area, we found a notable difference between the high-pressure sodium lamp and the HMLI mixed lamp $(\mathrm{p}<0.02)$, and between the compact fluorescent tube $(\mathrm{p}<0.001)$. In the urban area we found a notable difference between the HMLI mixed lamp and the compact fluorescent tube $(\mathrm{p}<0.04)$ (Table 3).

Table 3. Comparison of light sources based on catch number average in the transitional and in the urban area

\begin{tabular}{llcc}
\hline Area & & p value & \\
\hline Transitional & & Lamp & \\
\hline \multirow{2}{*}{$\begin{array}{l}\text { Order } \\
\text { Lepidoptera }\end{array}$} & High-pressure sodium lamp & High-pressure sodium lamp & HMLI mixed lamp \\
& HMLI mixed lamp & & \\
& Compact fluorescent tube & $\mathrm{p}<0.02$ & \\
Urban & & n.s. & \\
\hline \multirow{2}{*}{$\begin{array}{l}\text { Order } \\
\text { Lepidoptera }\end{array}$} & High-pressure sodium lamp & High-pressure sodium lamp & HMLI mixed lamp \\
& Compact fluorescent tube & & \\
& Comixed lamp & n.s. & \\
\hline
\end{tabular}

Based on location comparisons, we found notable dissimilarities in the average number of specimens trapped using the high-pressure sodium lamp and the compact fluorescent tube in the seminatural and transitional areas as well as between the seminatural $(\mathrm{p}<0.001)$ and the urban $(\mathrm{p}<0.001)$. We detected no considerable discrepancies in the averages in any of the locations with the HMLI mixed lamp; however, with the compact fluorescent tube, the difference between the seminatural and the transitional was $(\mathrm{p}<0.001)$, while the difference between the seminatural and urban locations was $(\mathrm{p}<0.001)($ Table 4).

According to lamp source, we identified 134 macrolepidopteran individuals from 13 species in the seminatural area in the spring of 2014. In the same location in the autumn, we identified 851 individuals from 11 Lepidopteran species using Varga (2010) nomenclature (1. appendix, 2. appendix).

We analysed the number of collected lepidopteran individuals using the Berger-Parker dominance test. The dominant species in the spring collected by the high-pressure sodium lamp was Colocasia coryli (L.1758), while in the autumn Operophtera brumata (L.1758) was the dominant species. With the HMLI mixed lamp and the compact fluorescent tube, the 
dominant lepidopteran species in the spring was Lycia hirtaria (C.1759), and in the autumn, it was Operophtera brumata (L.1758) (Table 5).

Table 4. Comparison of areas based on catch number averages using high-pressure sodium lamp, HMLI mixed lamp and compact fluorescent tube

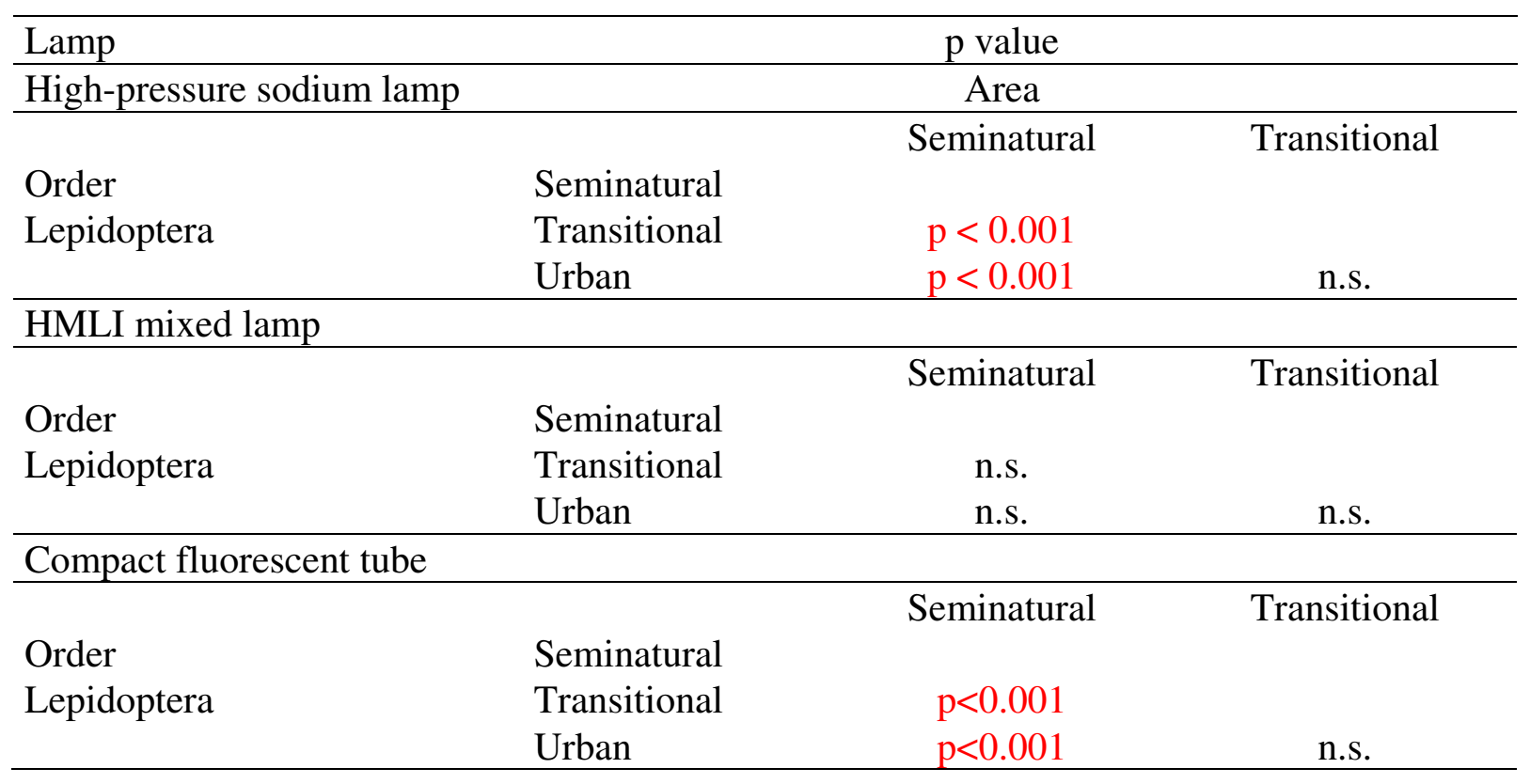

Table 5. Berger-Parker dominance index of Lepidoptera species

\begin{tabular}{llll}
\hline \multicolumn{2}{c}{ Berger-Parker dominant index (D) } \\
Month & Lamp & Species & D value \\
\hline March-April & High-pressure sodium lamp & Colocasia coryli (Linnaeus, 1758) & 0.5455 \\
October-November & High-pressure sodium lamp & Operophtera brumata (Linnaeus, 1758) & 0.2552 \\
March-April & HMLI mixed lamp & Lycia hirtaria $($ Clerk, 1759) & 0.6857 \\
October-November & HMLI mixed lamp & Operophtera brumata (Linnaeus, 1758) & 0.4220 \\
March-April & Compact fluorescent tube & Lycia hirtaria (Clerk,1759) & 0.3889 \\
October-November & Compact fluorescent tube & Operophtera brumata (Linnaeus, 1758) & 0.6118 \\
\hline
\end{tabular}

We compared the species similarity of nocturnal lepidopteran communities according to the three light sources and determined that the similarity comparison of the communities was highest with the HMLI mixed lamp and the compact fluorescent tube, while in the autumn the highest similarity was the high-pressure sodium lamp and the compact fluorescent tube (Table 6).

Table 6. Jaccard similarity coefficient in the spring and in the autumn

\begin{tabular}{lcccc}
\hline \multicolumn{4}{c}{ Jaccard similarity coefficient } & \\
Lamp & \multicolumn{2}{c}{ March-April } & October-November \\
\cline { 2 - 5 } & $\begin{array}{c}\text { High-pressure } \\
\text { sodium lamp }\end{array}$ & $\begin{array}{c}\text { HMLI } \\
\text { mixed lamp }\end{array}$ & $\begin{array}{c}\text { High-pressure } \\
\text { sodium lamp }\end{array}$ & $\begin{array}{c}\text { HMLI mixed } \\
\text { lamp }\end{array}$ \\
\hline Compact fluorescent tube & 0.22 & 0.42 & 0.9 & 0.82 \\
HMLI mixed lamp & 0.2 & & 0.73 & \\
\hline
\end{tabular}


We found the greatest similarity when investigating density in the spring between the high-pressure sodium lamp and the compact fluorescent tube, while in the autumn the closest similarity in terms of density was between the HMLI mixed lamp and the compact fluorescent tube (Table 7).

Table 7. Bray-Curtis similarity index in the spring and in the autumn

\begin{tabular}{lcccc}
\hline \multicolumn{5}{c}{ Bray - Curtis similarity index } \\
Lamp & \multicolumn{2}{c}{ March-April } & October-November \\
\cline { 2 - 5 } & $\begin{array}{c}\text { High-pressure } \\
\text { sodium lamp }\end{array}$ & $\begin{array}{c}\text { HMLI } \\
\text { mixed lamp }\end{array}$ & $\begin{array}{c}\text { High-pressure } \\
\text { sodium lamp }\end{array}$ & $\begin{array}{c}\text { HMLI mixed } \\
\text { lamp }\end{array}$ \\
\hline Compact fluorescent tube & 0.55 & 0.24 & 0.59 & 0.6 \\
HMLI mixed lamp & 0.17 & & 0.54 & \\
\hline
\end{tabular}

The diversity indices for macrolepidopteran communities showed the greatest values in the spring with the compact fluorescent tube, while in the autumn the greatest values occurred with the high-pressure sodium lamp (Simpson, Shannon, Pielou equitability) (Table 8, 9).

Table 8. Diversity indices in the spring

\begin{tabular}{lccc}
\hline Month & \multicolumn{3}{c}{ March-April } \\
Species richness & $\begin{array}{c}\text { Lamp } \\
\text { High-pressure }\end{array}$ & $\begin{array}{c}\text { HMLI mixed } \\
\text { sodium lamp }\end{array}$ & $\begin{array}{c}\text { Compact fluorescent } \\
\text { tube }\end{array}$ \\
\hline Simpson index & 0.562 & 0.511 & 0.772 \\
Shannon index & 0.917 & 1.199 & 1.749 \\
Pielou equitability & 0.834 & 0.546 & 0.841 \\
\hline
\end{tabular}

Table 9. Diversity indices in the autumn

\begin{tabular}{lccc}
\hline Month & \multicolumn{3}{c}{ October-November } \\
Species richness & $\begin{array}{c}\text { Lamp } \\
\text { High-pressure } \\
\text { sodium lamp }\end{array}$ & $\begin{array}{c}\text { HMLI mixed } \\
\text { lamp }\end{array}$ & $\begin{array}{c}\text { Compact fluorescent } \\
\text { tube }\end{array}$ \\
\hline Simpson index & 0.804 & 0.748 & 0.585 \\
Shannon index & 1.782 & 1.703 & 1.290 \\
Pielou & 0.811 & 0.739 & 0.560 \\
equitability & & & \\
\hline
\end{tabular}

By comparing the lepidopteran community diversity profile to the three types of lamp sources, we determined that the community trapped in the spring using the compact fluorescent tube was more diverse than the community trapped using the high-pressure sodium lamp. In addition to this, from the perspective of lepidopteran diversity, the communities trapped with the HMLI mixed lamp and the high-pressure sodium lamp cannot be ranked (Figure 1). 


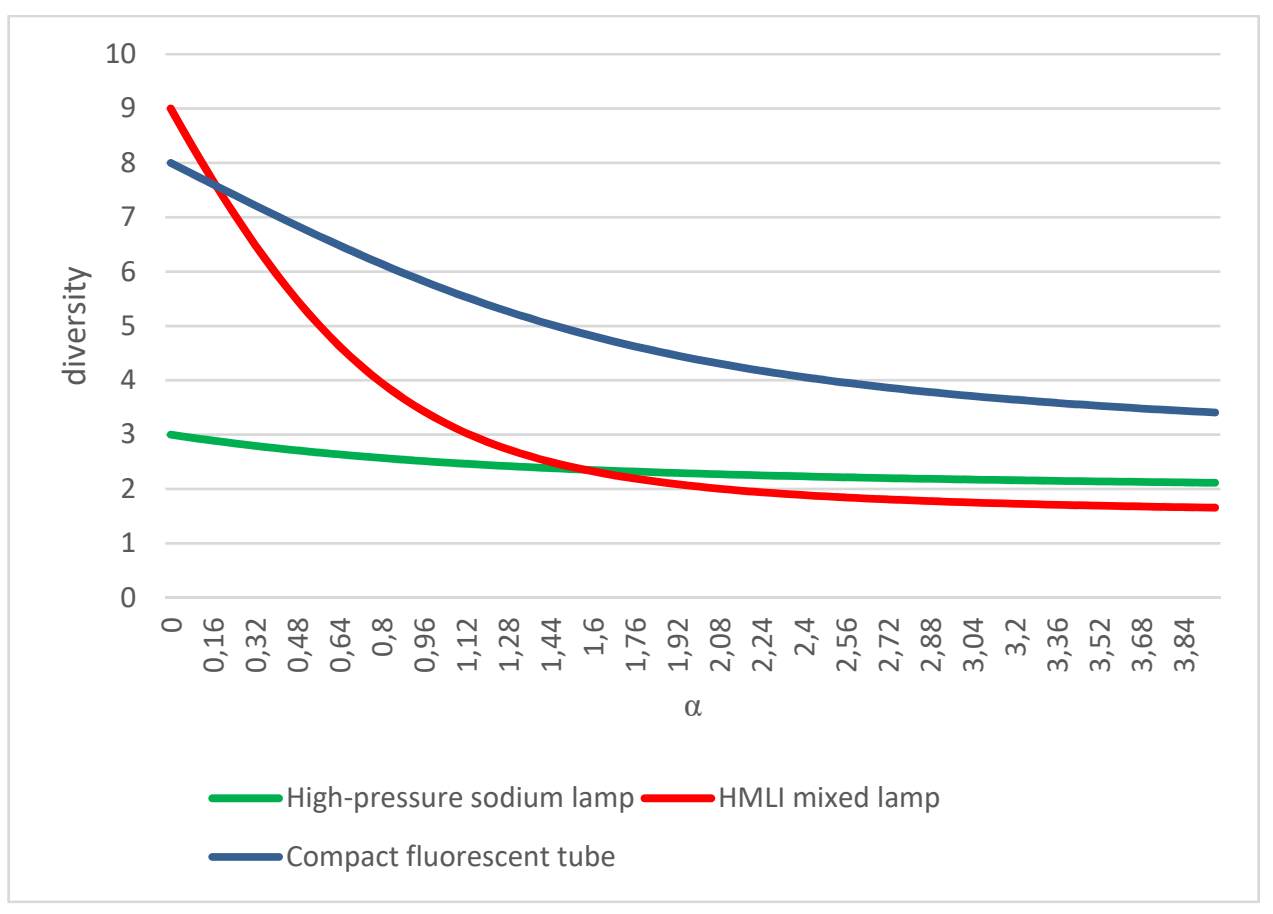

Figure 1. Rényi diversity graph in the spring according to the three lamp sources

The lepidopteran community collected with the HMLI mixed lamp in the autumn is more diverse than the community collected with the compact fluorescent tube. The graph lines of the high-pressure sodium lamp, the HMLI mixed lamp, and the compact fluorescent tube all intersect on the graphs; therefore, the diversity of the light-trapped macrolepidopteran communities cannot be ranked by lamp source (Figure 2).

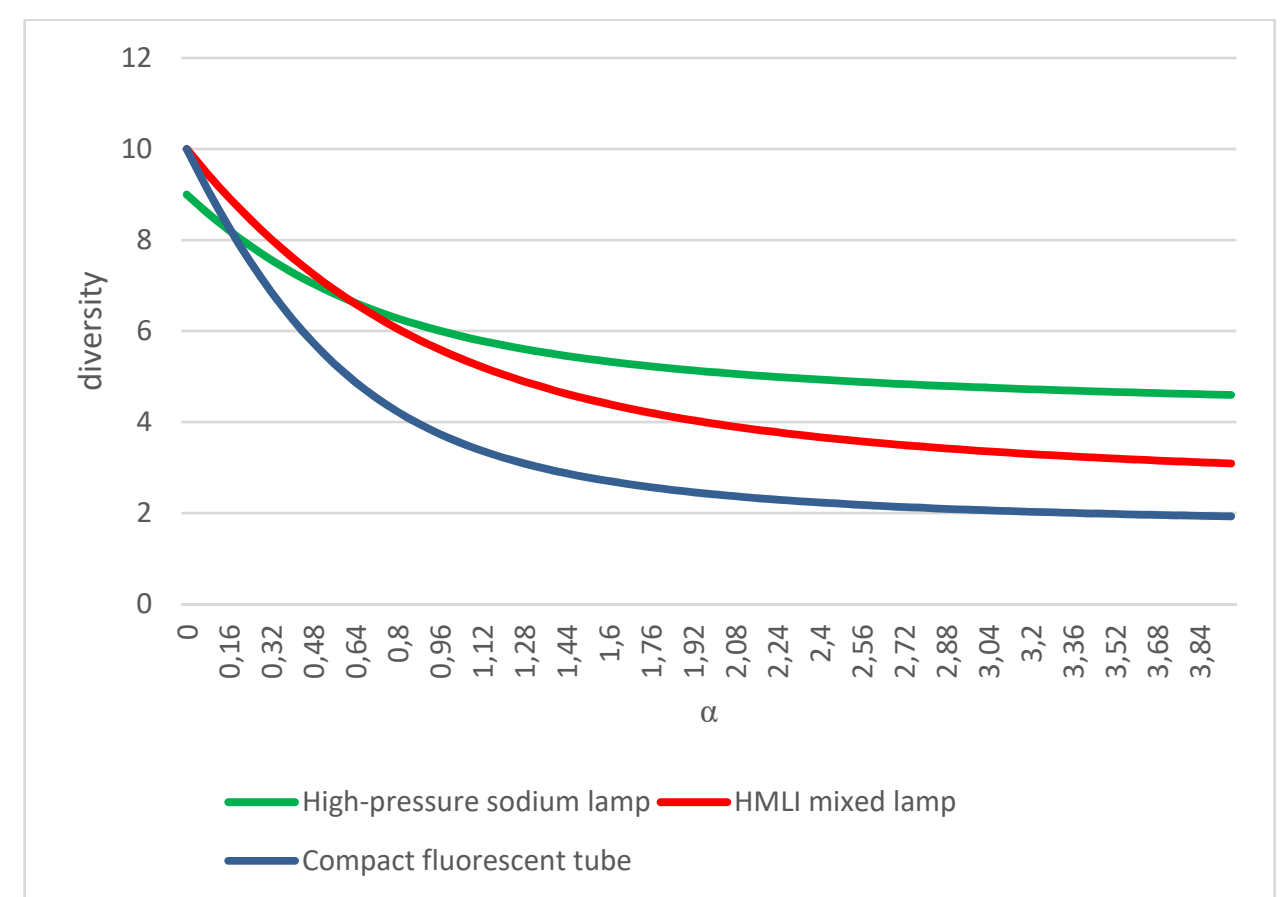

Figure 2. Rényi diversity graph in the autumn according to the three lamp sources 


\section{DISCUSSION}

A study employing methods similar to ours was completed in rural Germany (Eisenbeis Hassel 2000). As in our research, the German study used various locations to complete their light-trapping: the residential area of the town of Sulzheim, a more rural agricultural location with farmhouses, and a road near the edge of the Sulzheim settlement; although the study did not specify, we assumed that this area had different environmental illumination. The types of light used were high-pressures mercury vapour $(80 \mathrm{~W})$, high-pressure sodium vapour ( 70 or $50 \mathrm{~W}$ ), high-pressure sodium-xenon vapour lamps $(80 \mathrm{~W})$, and for special purposes, some of the high-pressure mercury vapour lamps were fitted with ultraviolet absorbing filters. The number of collected insects was the greatest with the high-pressure mercury vapour lamp. The light sources used in the abovementioned study are different from the ones we used in our study; thus, the results of the two studies are incomparable. One new and innovative method in our study is the selection of light-trapping areas based on the light pollution in each given area. There were no significant differences in the average number of individuals trapped in the seminatural site; notable dissimilarities occurred only in the transitional and urban sites. From this, we can conclude that background illumination has a meaningful effect on trapping distance or, put another way the attraction distance, of the light sources. We come to the similar conclusion if we compare the sites by lights because in two cases there were significant differences: between the seminatural and the urban, and between the seminatural and the transitional sites.

In our study, we used light traps with three different light sources in the area of Sopron and the Sopron highlands. Many faunistic investigations concerning nocturnal macrolepidopteran communities have been completed in this location (Leskó - Ambrus 1998, Sáfián et al.2009, Sáfián - Szegedi 2008, Horváth - Lakatos 2014, Horváth et al. 2013), but none employed methods that were similar to ours. The results gathered and compiled for the seminatural area cannot be considered complete due to the small number of specimens collected by light-trapping; nevertheless, the research studies still point to which nocturnal lepidopteran species are attracted to artificial lights in the spring and in the autumn. Therefore, our study draws attention to the potential danger artificial lights pose to certain nocturnal lepidopteran species. The basis of our results prove that in the spring individuals of the Lycia hirtaria (Clerk, 1759) species were drawn by the highest number to the HMLI mixed lamp, while individuals of Colocasia coryli (Linnaeus, 1758) species were attracted by the highest number to the high-pressure sodium lamp. In the autumn, individuals of Operophtera brumata (Linnaeus, 1758) species were attracted high-pressure sodium lamp in the highest number.

The type of light sources is not the only factor that influences the light attraction of individuals from the microlepidopteran and macrolepidopteran species (Mészáros 1966, Nowinszky - Ekk 1996, Puskás - Nowinszky 2011, Ábrahám et al. 2009, Frost 1954) the height positioning of the light also plays a role. This can be an especially important factor in the case of street lamps (Bürgés 1997). In our study, we positioned our light traps at a $2 \mathrm{~m}$ height from the ground. Before we embarked on the research, we assumed that the highpressure sodium lamp would produce the greatest diversity index values in every season, because it was the light source with the highest luminosity value. In contrast, the results show that according to the Shannon, Simpson, and Pielou equitability indices, values are the highest in the spring with the compact fluorescent tube, whereas the high-pressure sodium lamp showed the highest values in autumn.

The similarity between macrolepidopteran communities in the spring and autumn with the HMLI mixed lamp $(3100 \mathrm{~lm})$ and the compact fluorescent tube $(2900 \mathrm{~lm})$ could be 
attributed to the similar luminosity of the two light sources. This condition is apparent in the diversity profile as well.

The results confirm our supposition that the greatest number of collected lepidopteran individuals occurred in the seminatural area. Therefore, artificial light sources may decrease the number of lepidopteran individuals. The results also partly support another of our supposition - the diversity of Lepidoptera communities was the greatest by compact fluorescent tube in the spring and by high-pressure sodium lamp in the autumn. Our results illustrate the diverse sensitivity of lepidopteran species to different lamps.

The results demonstrate that from a nature protection point of view, artificial lights can negatively affect the environment of lepidopteran communities.

For further investigation and for a better understanding of the effect artificial lights have on Lepidoptera communities, we would require more areas, sites, dates, and lights.

Acknowledgements: We would like to thank Institute of Geomatics, Forest Exploration, and Water Management Institute at the Faculty of Forestry of the University of West Hungary and the Meteorological Station in Sopron for ensuring and providing the research sites used for this study.

\section{REFERENCES}

ÁBrAHÁM, L. - UHERKOVICH, Á. - SzEŐKE, K. (2009): Nagylepke fauna felmérése a Biodiverzitás Napok alkalmából a zselici Gyürüfün (Lepidoptera: Macrolepidoptera). [Asessment of Macrolepidoptera during the Gyürüfü Biodiversity Days in Zselic.] Natura Somogyiensis 13: $169-178$.

BROwN, L.N. (1984): Population outbreak of Pandora moths (Coloradia pandora Blake) on the Kaibab plateau, Arizona (Saturniidae). Journal of the Lepidopterist's Society 38, 65.

BÜRGÉs, GY. (1997): A fény erőssége, színe, kihelyezés magassága és a fogott rovaranyag közötti összefüggés vizsgálata. IV. [An examination of the relationship between the effects of intensity, colour of light, and placement of light traps and light-trapped insects] Magyar Ökológus Kongresszus Előadások és poszterek összefoglalói. (in Hungarian)

CARvalheiro, L.G. - Kunin, W. E. - Keil, P. - Aguirre-Gutiérrez, J. - Ellis, W.N. - Fox, R. (2013): Species richness declines and biotic homogenisation have slowed down for NWEuropean pollinators and plants. Ecology Letters 16: 870-878.

DöVÉNYI Z. (ed.) (2010): Magyarország kistájainak katasztere - Második, átdolgozott és bővített kiadás. [Cadastre of microregions in Hungary] MTA Földrajztudományi Kutatóintézet, Budapest. 876 p. (in Hungarian)

EISENBEIS, G. - HASSEL, F. (2000): Attraction of nocturnal insects to street lights - a study of unicipal lighting systems in a rural area of Rheinhessen (Germany). Natur und Landschaft 75 (4): 145-156.

FoX, R. - Oliver, T. H. - HARrover, C. - PARsons, M.S. - ThOMAS, C.D. - RoY, D.B. (2014): Long-term changes to the frequency of occurence of British moths are consistent with opposing and synergistic effects of climate and land-use changes. Journal os Applied Ecology 51: 949-957.

FROST S. W. (1954): Response of insects to black and white light. Journal of Economic Entomology 47 (2): 275-278.

HAMMER, O. (2012): PAST PAleontological STatistics, Version 2.17. Reference manual. Natural History Museum, University of Oslo, 229 pp. Elérhetőség: http://www.nhm2.uio.no/norlex/past/pastmanual.pdf (Letöltve: 2015.04.10.)

HeILING, A. M. (1999): Why do nocturnal orb-web spiders (Araneidae) search for light? Behavioral Ecology and Sociobiology 46: 43-49.

Henderson, R. W. - POWELL, R. (2001): Responses by the West Indian herpetofauna to humaninfluences resources. Caribbean Journal of Science 37: 41-54. 
HORVÁTH, B. - LAKATOS, F. (2014): Éjszakai nagylepkék diverzitásának vizsgálata különböző korú gyertyános-kocsánytalan tölgyes erdóállományokban. [Monitoring of diversity of nocturnal Macrolepidoptera in the different aged Sessile hornbeam-oaken forests] Erdészettudományi Közlemények 4 (1): 185-196.

HoRvÁth, B. - TÓTH, V. - KovÁCS, GY. (2013): The effect of herb layer on nocturnal Macrolepidoptera (Lepidoptera: Macroheterocera) communities. Act. Silv.Lign.Hung. 9: 43-56.

HoRVÁth, G. - MALIK, P. - KRISKA, GY. (2009): Poláros fényszennyezés. [Polarised light pollution.] Környezetfizikai Módszerek Labóratóriumi Gyakorlat. (in Hungarian)

Howe, W. H. (1959): A swarm of noctuid moths in southeastern Kansas. Journal of the Lepidopterist's Society 13,26.

HÖLKER, F. - WOlTER, C. - PERKIN, E. K. - TOCKNER, K. (2010): Light pollution as a biodiversity threat. Trends in Ecology \& Evolution, 25: 681-682.

KEMÉNY, S. - DEÁK, A. - KoMKA, K. - VÁGÓ, E. (2011): Hogyan használjuk a STATISTICA programot? [How to use the STATISTICA program?] Perfact Kiadó, Budapest (in Hungarian)

KovÁCS, L. (1962): Zehn Jahre Lichtfallenaufnahmen in Ungarn. Ann. Hist. - nat. Mus. Nat. Hung. (54): 365-375.

KREBS, C.J.(1985): Ecology: The experimental analysis of distribution and abundance Third Edition. Harper \& Row Publishers New York: 521-523.

LESKÓ, K. - AMBRUS, A. (1998): Sopron környékének nagylepkefaunája fénycsapdás gyüjtések alapján. [Macrolepidoptera fauna based on light trappings in the surrounding of Sopron.] Erdészeti Kutatások 88: 273-304. (in Hungarian)

MC GAVIN, G.C. (2000a): Rovarok, pókok és más szárazföldi ízeltlábúak. [Insects, spiders and other terrestrial arthropods] Dorling Kindersley Book, London 2000.

MC GAVIN, G.C. (2000b): Rovarok. [Insects] Panemex Grafo Kiadó Budapest 2000.

MC GAVIN, G.C. (2005): Rovarok és pókok. [Insects and spiders] Dorling Kindersley Book, London 2004

MACGREGOR et al. (2015): Pollination by nocturnal Lepidoptera, and the effects of light pollution: a rewiew. Ecological Entomology 40:187-198.

MÉSZÁros, Z. (1966): Normál és ultraibolya fénycsapdák Microlepidoptera anyagának összehasonlítása. [A comparison of light-trap catch of Microlepidoptera species trapped by normal and UV light.] Rovartani Közlemények XIX. (3): 113-133 (in Hungarian)

NEMEC, S. J. (1969) Use of artificial lighting to reduce Heliothis spp. populations in cotton fields. Journal of Economic Entomology 62: 1138-1140.

NOWINSZKY, L. - EKK, I. (1996): Normál és UV fénycsapdák Macrolepidoptera anyagának összehasonlítása. [A comparison of light - trap catch of Macrolepidoptera species trapped by normal and UV light.] Növényvédelem 32(11): 557-567.

PFrimMer, T. R. - LuKEFAHR, M.J. - HOLLINGSWORTH, J. P. (1955): Experiments with Light Traps for Control of the Pink Bollworm. ARS-33-6. U.S. Department of Agriculture, Agricultural Research Service, Washington, District of Columbia

Potts, S. G. - Biesmeijer, J. C. - Kremen, C. - Neumann, P. - Schweiger, O. - Kunin, W. E. (2010): Global pollinator declines: trends, impacts and drivers. Trends in Ecology \& Evolution 25: 345-353.

PUSKÁS, J. - NOWINSZKY, L. (2011): Light-trap catch of Macrolepidoptera species compared the $100 \mathrm{~W}$ normal and $125 \mathrm{~W}$ BL lamps. Acta Naturalia Pannonica 2 (2): 179-192.

RAMAMURTHY, .V.V. - AKHTAR, M.S. - PATANKAR, N.V. - MENON, P. - KUMAR, R. - Singh, S.K. AYRI, S. - PARVEEN, S. - MiTTAL, V. (2010): Efficiency of different light sources in light traps in monitoring insect diversity. Munis Entomology \& Zoology, 5 (1): 109-114.

RAUP, D. - CRICK, R. E. (1979): Measurement of faunal similarity in paleontology. Journal of Paleontology 53: 1213-1227.

REICHHOLF-RIEHM, H. (1996): Lepkék. [Butterflies] Magyar Könyvklub, Budapest. (in Hungarian)

RYDELL, J. (1992): Exploitation of insects around streetlamps by bats in Sweden. Funct Ecology 6: 744-750.

SÁFIÁN, SZ. - SZEGEDI, B. (2008): A behurcolt tölgy-selyemlepke (Antherae yamamai GuérinMéneville, 1861) (Saturniidae: Lepidoptera) megjelenése a Soproni-hegyvidéken. [The 
apperaence of Japanese Oak Silkmoth (Antharae yamamai Lepidoptera: Saturniidae), an introduced species in the Sopron Mountains (North-West Hungary)]. Szélkiáltó 13: 29. (in Hungarian)

SÁfián, Sz. - Ambrus, A. - HoRVÁth, B. (2009): Új fajok Sopron környékének éjjeli nagylepkefaunájában (Lepidoptera: Macroheterocera). [New nocturnal Macrolepidoptera species in the fauna of Sopron and its vicinity (Lepidoptera:Macroheterocera.] Praenorica Folia Historico-Naturalia 11: 189-201. (in Hungarian)

SouTHWOOD, T. R. E. (1984): Ökológiai módszerek- különös tekintettel a rovarpopulációk tanulmányozására. [Ecological methods - with especial regard to investigation the population of insects.] Mezőgazdasági Kiadó, Budapest. 280 p.

SOWER, L.L. - SHOREY, H. H. - GASTON, L.K. (1970): Sex pheromones of noctuid moth. XXI. Light: dark cycle regulation and light inhibition of sex pheromone release by females of Trichoplusia ni. Annals of the Entomological Society of America 63: 1090-1092.

STERRY, P. - MACKAY, A. (2004): Lepkék. [Butterflies] Dorling Kindersley Book, London 2004

TÓTHMÉRÉSZ, B (1997): Diverzitási rendezések. Scienta Kiadó, Budapest. 98 p.(in Hungarian)

WALKER, A.K. - GALBREATH, R.A. (1979): Collecting insects at lights: a test of four types of lamp. New Zealand Entomologist, 7 (1): 83-85.

WILLIAMS, P.H. (1982): The distribution and declines of British bumble bees (Bombus Latr.). Journal of Apicultural Research 21: 236-245.

VARGA, Z. (ed.) (2010): Magyarország nagylepkéi. [Macrolepidotera of Hungary.] Heterocera Press, Budapest. 


\section{APPENDIX}

Appendix 1: The number of lepidopteran individuals collected by light source in the spring

\begin{tabular}{lccc}
\hline \multicolumn{1}{c}{ Date } & \multicolumn{2}{c}{ Lamp } \\
March-April & $\begin{array}{c}\text { High-pressure sodium } \\
\text { lamp }\end{array}$ & $\begin{array}{c}\text { HMLI mixed } \\
\text { lamp }\end{array}$ & $\begin{array}{c}\text { Compact fluorescent } \\
\text { tube }\end{array}$ \\
\hline Lycia hirtaria & 4 & 72 & 7 \\
Colocasia coryli & 6 & 11 & 4 \\
Ectropis & & & \\
crepuscularia & 1 & 0 & 0 \\
Conistra vaccinii & 0 & 4 & 0 \\
Orthosia cruda & 0 & 6 & 0 \\
Orthosia incerta & 0 & 3 & 2 \\
Endromis versicolora & 0 & 4 & 0 \\
Orthosia gothica & 0 & 3 & 1 \\
Lampropteryx & & & 0 \\
Suffumata & 0 & 1 & 1 \\
Polyploca ridens & 0 & 1 & 1 \\
Panolis flammea & 0 & 0 & \\
Euphia biangulata & 0 & 0 & 0 \\
Selenia dentaria & 0 & 0 & \\
\hline
\end{tabular}

Appendix 2: The number of lepidopteran individuals collected by light source in the autumn

\begin{tabular}{lccc}
\hline \multicolumn{1}{c}{ Date } & Lamp & \\
October-November & $\begin{array}{c}\text { High-pressure sodium } \\
\text { lamp }\end{array}$ & HMLI mixed lamp & $\begin{array}{c}\text { Compact fluorescent } \\
\text { tube }\end{array}$ \\
Species & 10 & 22 & 2 \\
\hline Colotois pennaria & 36 & 50 & 23 \\
Erannis defoliaria & 5 & 8 & 4 \\
Asteroscopus sphinx & 3 & 0 & 1 \\
Conistra vaccinii & 71 & 5 & 1 \\
Epirrita dilutata & 24 & 85 & 24 \\
Ptilophora plumigera & 74 & 165 & 104 \\
Operophtera brumata & 63 & 25 & 6 \\
Operophtera fagata & 4 & 13 & 0 \\
Agriopis aurantiaria & 0 & 2 & 2 \\
Eriogaster rimicola & 0 & 16 & \\
Poecilocampa populi & & & \\
\hline
\end{tabular}




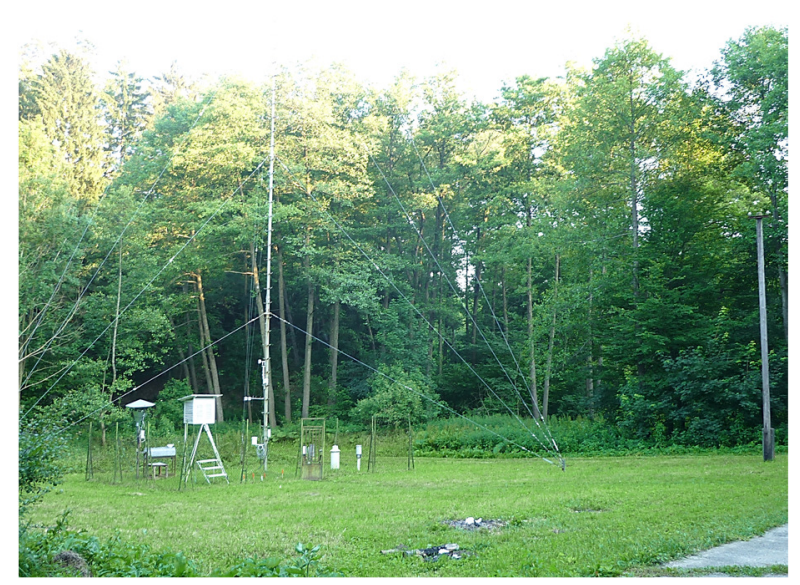

Photo 1: Seminatural, light pollution free site

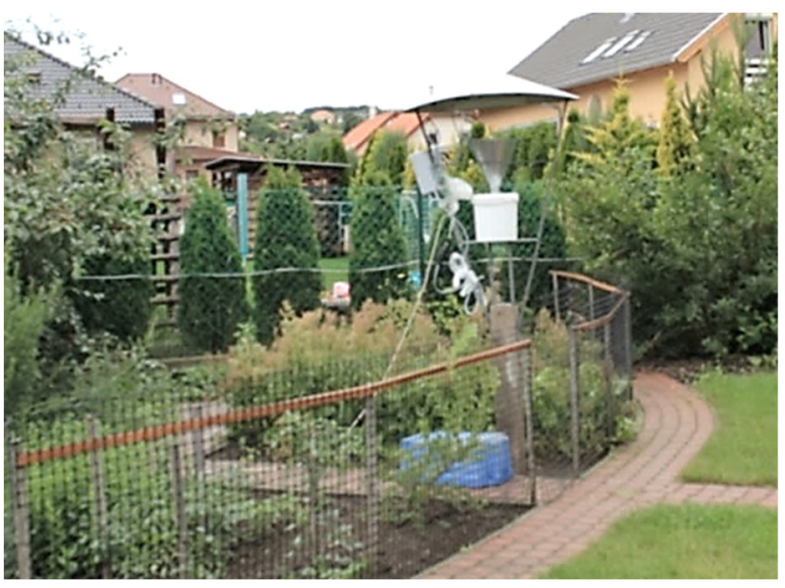

Photo 2: Transitional, site with slight pollution

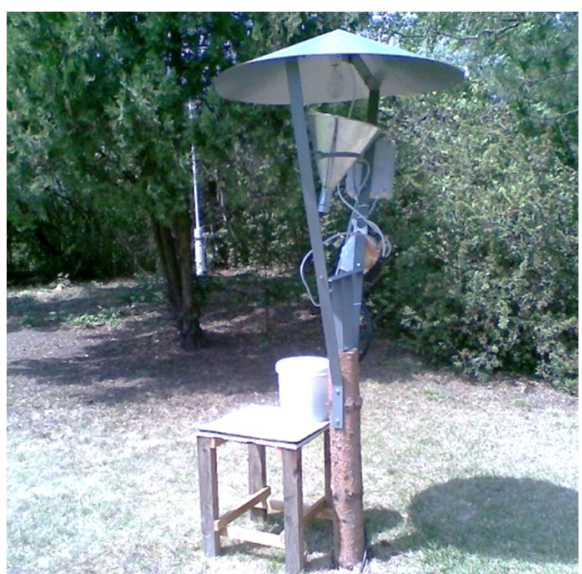

Photo 3: Urban site with considerable light pollution

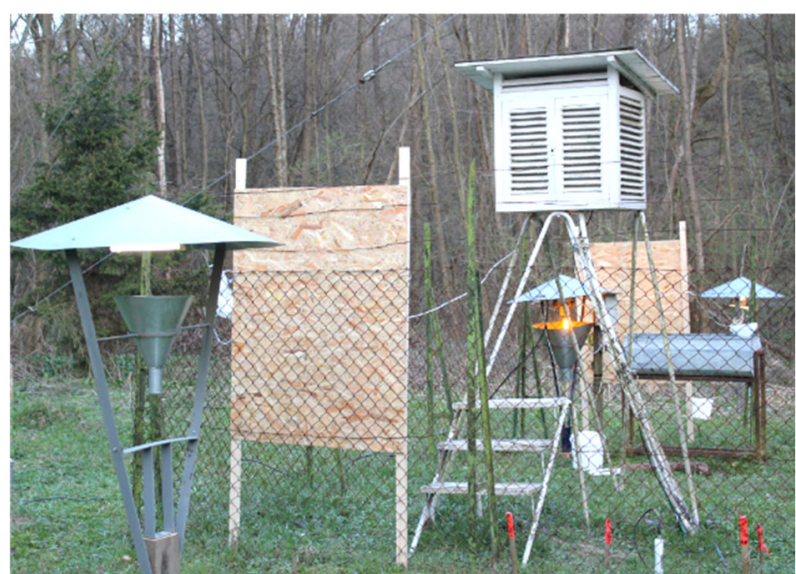

Photo 4: Simultaneously operating light traps in the seminatural site 